\title{
FEDERALISMO FISCAL E AMAZÔNIA: O FINANCIAMENTO PÚBLICO DIANTE DAS CONTRADIÇÕES REGIONAIS NO BRASIL
}

\section{Cleyson Silva dos Santos ${ }^{1}$}

\section{INTRODUÇÃO}

Diante do debate em que o Brasil se insere, no contexto atual de retração fiscal2 ${ }^{2}$, as contas públicas do país ganham forte destaque mediante os diversos questionamentos quanto à responsabilidade e dimensão do problema. A questão tomou outras proporções principalmente, quando, após alguns períodos de forte centralização fiscal e, portanto, centralização da oferta de bens públicos por parte da União, a mais recente Constituição Federal promulgada em 1988, trouxe novos mecanismos que dissiparam esse controle para estados e municípios. A partir disso, o debate perpassa em compreender o problema por vias de uma incapacidade econômica que agora é estrutural, e que apresenta disparidades em diferentes análises. Tais análises não deixam escapar uma disparidade que é fundamental: as características econômicas fiscais.

É nesse sentido que o trabalho desenvolvido busca compreender as relações federativas nacionais e suas contradições regionais. Ela se dá por meio da análise do contexto federativo brasileiro e especificamente sua relação com as condições de financiamento dos estados amazônicos vis-à-vis as demais regiões. Essa é uma abordagem relevante, pois como observaram diversos autores (KHAIR, 2006; PRADO, 2006b; SANTOS et. al., 2001, entre outros) foi demonstrado que as mudanças no sentido de alterações federativas consolidadas nas duas últimas décadas levaram os governos estaduais e as prefeituras municipais a assumirem uma maior capacidade autônoma. Essa capacidade estatutária constitucional se manifesta tanto nos aspectos de autonomia de receitas e controle sobre uma maior massa de recursos efetivos, quanto pelas atribuições que passaram a deter, antes de competência da União.

Nesse sentido, o presente artigo objetiva compreender como as diferentes unidades subnacionais buscam equacionar a relação entre investimento público e financiamento do mesmo, considerando tanto as receitas primárias, quanto as receitas provenientes da tomada de dívidas. O cerne central, portanto, é demonstrar o nexo causal deste trabalho: analisar as disparidades

\footnotetext{
${ }^{1}$ Economista pela Universidade Federal do Pará (UFPA). Mestrando em Desenvolvimento Econômico pelo Instituto de Economia (IE) da Universidade Estadual de Campinas (UNICAMP). Pesquisador da Centro de Estudos do Desenvolvimento Econômico (CEDE/IE/UNICAMP). E-mail: cleysonsil@ hotmail.com

2 Segundo o Comitê de Datação do Ciclo Econômico (Codace) da Fundação Getulio Vargas. O produto per capita brasileiro caiu cerca de $9 \%$ entre 2014 e 2016.
} 
regionais de financiamento e investimento, com base nos estados selecionados e de acordo com a conformação de um novo regime de política fiscal em curso no país, o qual orientou o corte temporal deste trabalho: 2000 - 2013. Além disso, tem-se como foco demonstrar o papel da estrutura tributária, de dívida pública, e dos gastos públicos (principalmente os de infraestrutura e com Capital) na configuração do atual cenário nacional. Esta parte é, sem dúvidas, uma das mais importantes, pois sintetiza as conclusões dos capítulos anteriores, além de concluir o processo argumentativo.

Como já salientado no início, este trabalho visa a analisar como as diferentes unidades subnacionais buscam equacionar a relação entre investimento público e financiamento do mesmo, considerando tanto as receitas primárias, quanto as receitas provenientes da tomada de dívidas.

A fim de realizar esta análise e contribuir para o debate do federalismo fiscal no Brasil, este trabalho segue dividido, além desta introdução, em quatro seções, algumas subseções e uma conclusão. A primeira seção traz uma revisão de Literatura, na qual se busca contextualizar, fazer uma exposição histórica e abordar a trajetória institucional do federalismo fiscal no Brasil, posteriormente serão discutidos os aspectos acerca do marco regulatório, Dívida pública estadual e distorções no financiamento público brasileiro. A partir disso, serão apresentados os aspectos metodológicos, bem como demonstrados os indicadores a serem utilizados, para enfim se discutir as distorções no financiamento público dos Estados selecionados com base na análise de dados.

\section{TEORIA DO FEDERALISMO E FEDERALISMO FISCAL: FUNDAMENTOS E FUNÇÕES FISCAIS}

Por trás do termo Federalismo pode-se identificar sua forte relação com as formas de Estados nacionais. Nesse sentido, a organização do aparato estatal pode ser vista como uma distribuição de poder político dentro de seu território que converge para a gestão do sistema de governo adotado. Essa organização do aparato, ou seja, da forma estatal nacional pode se diferenciar entre as distintas nações à medida que, algumas federações são altamente centralizadas, concentrando todo o poder nas mãos do governo federal, enquanto outras apresentam intenso grau de descentralização e conferem considerável autonomia às unidades constitutivas (ANDERSON, 2009).

Atrelado ao entendimento da derivação da forma estatal, é possível identificar também 0 meio de instauração de um sistema de governo, ele se dá via unificação ou divisão administrativa, nesse último caso, em estados, municípios, ou outras unidades, constituindo portanto, instituições políticas, as quais são subsidiárias (podendo ter mais ou menos atribuições) aquela forma estatal estabelecida. Tais elementos (sistema de governo, divisão de atribuições, partilha de poder) se aglutinam naquilo que aqui denominamos Federalismo. 
Conforme observado em Anderson (2009) por Federalismo entende-se uma forma de governo estatal cuja característica essencial se encontra no poder de jurisdição por parte de um governo central, ao mesmo tempo em que nele há outros governos com jurisdições regionais e com distintos graus de autonomia (quanto ao trato administrativo, gerenciamento de políticas diversas, e financeiro) e que possui, portanto, subdivisões internas ao território (estados, municípios, províncias, etc.).

De um modo geral, a ideia fundamental subjacente ao estudo do Federalismo é a de descentralização sendo essa exposta através de dois elementos de destaque:

Se é que existe elemento essencial ao federalismo, este vem a ser a presença de duas ordens de governo constitucionalmente instituídas, cada qual dotada de genuína autonomia uma em relação à outra e responsáveis perante os respectivos eleitores. (ANDERSON, 2009, p. 20.)

Além desta, dentre as características ${ }^{3}$ de grande relevância para uma análise mais detida do Federalismo há outras que ganham destaque, tais como a presença de uma constituição escrita, que pressupõe as "regras institucionais" preestabelecidas as quais só podem possuir emendas mediante autorização das outras unidades de governo; nela deve constar atribuições objetivas de competência legislativa, incluindo na área fiscal, assegurando, portanto, autonomia aos entes federados. Ademais, o federalismo pressupõe representatividade na tomada de decisões, bem como procedimentos, processos e instituições que facilitem a condução nas relações de decisão e disputas entre os entes federados.

Dentro do núcleo do Federalismo há um mecanismo de competência de repartição que é fundamental para o conjunto da economia e funcionamento do Estado federal: o mecanismo tributário. Tal mecanismo se caracteriza pelo sistema de partilha dos recursos públicos, e delimita a autonomia financeira e orçamentária dos entes federados.

O mecanismo tributário revela a necessidade de haver certa capacidade de arrecadação de cada ente nacional, nesse sentido, pode-se observar que diversos são os meios dos quais os recursos podem ser obtidos, cabe aqui ressaltar aqueles que possuem grande importância no conjunto do orçamento: arrecadações através do somatório das receitas obtidas por cada ente federal em suas respectivas competências tributárias, das receitas oriundas da exploração de atividades econômicas (comércio, agropecuária, indústria e serviços), das operações de crédito, da alienação de bens, do recebimento de amortização de empréstimos concedidos e ainda do superávit do orçamento corrente, dentre outros. Soma-se a isto, a quantia decorrente do sistema

\footnotetext{
3 Anderson (2009) aponta a existência de mais de uma forma de Estado, e elenca os traços comuns do Estado Federal, presentes em diferentes países tais como: Índia, Espanha, África do Sul, Austrália e Brasil.
} 
de repartição de receitas e de transferências intergovernamentais, que podem ser voluntárias ou obrigatórias.

Nesse sentido, temos, portanto, que o Federalismo Fiscal corresponde ao conjunto de mecanismos técnicos e jurídicos que balizam a distribuição da competência tributária entre os níveis constituintes da hierarquia federativa, dotando-os de poder legal para administrarem os impostos gerados sob sua jurisdição. No entanto, enquanto um processo histórico e político, outra tendência marca sua definição: é também um conjunto de regramentos subjacentes à forma como a federação encara o problema da usual disparidade inter-regional (de recursos, infraestrutura, produtividade), adotando mecanismo redistributivos (como os fundos de participação, transferências e demais mecanismos de partilha) de maneira mais ou menos incisiva no intuito de equacionar tais desníveis.

Qian e Weingast (1997) classificam duas gerações do federalismo fiscal, a chamada Primeira geração do federalismo fiscal defende uma maior descentralização como uma forma eficiente frente questões da microeconomia neoclássica tais como as externalidades e provisão de bens públicos, cuja divisão entre entes subnacionais (Estados e municípios), é justificada por vias da interpretação de distribuição, estabilização econômica e alocação de recursos ${ }^{4}$.

De outro modo, a segunda geração aborda a interação entre os níveis de governo e a influencia na tomada de decisões de um agente centralizador, de modo que nela destacam-se questões também microeconômicas, entretanto, no âmbito da assimetria de informações e no problema do agente principal. Vale ressaltar que neste capítulo serão relacionados os aspectos da primeira geração visto que a constituição de 1988 demonstra um caráter predominantemente descentralizador, portanto, problematizar tal teoria com os aspectos dominantes do federalismo fiscal brasileiro demonstra-se ser de suma importância, uma vez que conforme observou Rezende (2009) o federalismo fiscal brasileiro é acompanhado de desequilíbrios verticais e horizontais na repartição de receita tributária nacional.

Nesse sentido, a primeira geração do federalismo fiscal ressalta a importância de compreender quantos níveis de governo devem haver para que, de forma eficiente, sejam efetivadas as tarefas que convém ao estado, a saber - a provisão de bens públicos ${ }^{5}$. Assim, segundo Oates (1972, apud MORAIS, 2001, p. 85) "trata-se, pois, de analisar os prós e contras

\footnotetext{
${ }^{4}$ As funções clássicas do Estado são caracterizadas por Musgrave e Musgrave (1980) e contribuem para a teoria de descentralização.

5 A principal característica dos bens públicos, e que os distingue dos privados, refere-se à impossibilidade de excluir determinados indivíduos ou segmentos da população de seu consumo, uma vez definido o volume de produção. (REZENDE, 2007)
} 
de um sistema estatal mais ou menos descentralizado, a depender das funções a serem desempenhadas. Tal preocupação está no cerne da interpretação do federalismo fiscal pela ótica neoclássica.

O processo de centralização ou descentralização da organização estatal com base nas experiências modernas não possuem um único modelo eficiente. As especificidades dos processos históricos de desenvolvimento social, político e econômico de cada Estado-nação é que vão acabar por moldar os traços característicos de suas relações intergovernamentais (OATES, 1972, apud MORAIS, 2001). Deste modo, o governo pode, em tese, desempenhar as funções fiscais clássicas - alocação, distribuição e estabilização - e com base nesse conceito é que a teoria do federalismo fiscal organiza as decisões e a atuação de estado em mais de uma instância de governo.

Fazendo uso da análise atribuída por Morais (2001) um dos fundamentos para a constituição de um modelo de descentralização ou centralização do estado, dentro da primeira geração do federalismo fiscal, se baseia na problemática de alocação eficiente, deste modo, para o autor, a divisão em esferas de governo, cada qual baseado geograficamente e por competência, portanto um Estado descentralizado, conduz o governo a uma maior eficiência alocativa.

Vale observar que o modelo que contribuiu para essa análise foi observado por Tiebout em 1956:

[...] partindo-se da hipótese simplificadora de que um Estado federal possui fronteiras geográficas nacionais e que, portanto, os demais níveis de governo existentes são uma subdivisão desse ente nacional. Supõe-se também que os recursos da economia, bem como a população, estão distribuídos espacialmente de uma determinada maneira no território nacional, o que implica fazerem os indivíduos parte de comunidades locais - onde atuam na escolha e determinação de bens e serviços públicos -, antes de serem cidadãos-membros do Estado nacional. (TIEBOUT, 1956, p. 416 apud MORAIS, 2001, p. 86)

Portanto, os bens públicos possuem diferentes alcances, uma vez que, ainda de acordo com Tiebout (1956), há mobilidade e informação perfeitas entre cidadãos, haja vista que há adaptação das preferências entre bens públicos e impostos. Assim, os cidadãos podem se deslocar sem nenhum custo para realizar essa adaptação. Essa mobilidade como resposta dos agentes econômicos é uma das principais contribuições do autor. Nessa mesma direção, Oates (1992) sugere a importância de alguns tributos serem conferidos pelos governos locais.

É importante ressaltar que tal perfeito equilíbrio defendido pelo federalismo fiscal clássico não se aplica no contexto contemporâneo, haja vista que conforme ressaltou Rezende (2007) existem dificuldades encontradas para fazer com que a descentralização das receitas fosse acompanhada de uma concomitante descentralização das responsabilidades públicas, em 
especial no campo das políticas sociais, portanto, há desequilibrios que precisam ser corrigidos e a necessidade de se fazer compatibilização de interesses entre os entes de uma dada nação, uma vez que que uma nação presume a existência de diversidade regional entre as partes e, portanto, a necessidade de se viabilizar um pacto federativo entre elas o qual define o suporte fiscal $\mathrm{e}$ socioeconômico caracterizado pela repartição entre os entes do Estado que resulta em um pacto federativo mais equânime. 6

Outro aspecto relevante acerca da eficiência alocativa de bens públicos é o fato de que grande parte desses bens não são puramente públicos, de modo que o proveito deles não inclui toda a população de um estado nacional, dessa forma, se infere que a sua oferta eficiente deve ocorrer nos níveis regionais ou locais.

Ademais, Morais (2001) observou que a utilidade propiciada é inversamente proporcional à distância do local de fornecimento, portanto, os bens públicos têm alcance nacional, regional ou local. Assim, a eficiência econômica relativa a função alocativa se realiza à medida que há perfeita correspondência entre as ações do governo e a preferência dos grupos que o financiam.

Por fim, cabe mencionar que, conforme afirma Morais (2001), outro motivo que também corrobora para a oferta descentralizada de bens públicos como mais eficiente do ponto de vista alocativo, são os custos de transação envolvidos na concentração da tomada de decisão, uma vez que torna-se um problema de agenda, portanto, que o poder da esfera legislativa nacional determine tantas combinações de preferências que maximizem as utilidades locais.

Para resolver o problema de custos de transação foi inicialmente cunhado por Olson em 1969 um novo termo na teoria do federalismo fiscal:

[...] esses governos devem financiar tais despesas com receitas próprias, coletadas daqueles cidadãos que se beneficiam dos bens públicos fornecidos. Dessa maneira, internalizam-se não só os benefícios como também os custos de fornecimento dos bens públicos regionais ou locais. Este é o chamado "Princípio da equivalência fiscal" (principle of fiscal equivalence) [...]. (MORAIS, 2001, p. 89)

Destarte, pelo "Princípio da equivalência fiscal" os bens públicos utilizados em níveis locais devem ser, em sua maioria, financiados por cidadãos que os usufruem e, portanto, esses níveis de governo locais devem ter autonomia para coletar receitas para seu financiamento. Isso propicia maior responsabilidade e melhor alocação dos gastos às suas preferências.

Além do critério de eficiência alocativa, outros aspectos fundamentam o grau de centralização e descentralização entre os níveis de governo, são eles: distribuição e estabilização.

6 Cf. ABRUCIO, 2002 
A meta de distribuição refere-se à minimização das desigualdades de renda e riqueza existentes entre os indivíduos e as regiões no interior de uma dada economia nacional, ao passo que a estabilização corresponde à manutenção do equilíbrio interno e externo das principais variáveis da economia (MORAIS, 2001).

Deste modo, é possível inferir que na fundamentação distributiva há, em sua composição, a mesma linha da eficiência alocativa, qual seja, a de descentralização. Dessa forma, é imposta a necessidade de distribuição, haja vista a presença de diferenças entre níveis de uma nação. No entanto, conforme analisa Cossio (1998), isso se aplica a questão da capacidade fiscal, uma vez que é possível que as diferenças de capacidade fiscal entre unidades de governo do mesmo nível deem lugar a uma oferta pública regionalmente desigual. Essa contrapartida causa um movimento de indivíduos de diferentes localidades que, "além de neutralizar os efeitos da política redistributiva, vai onerar ainda mais as necessidades de gastos dessa comunidade" (MORAIS, 2001, p. 90).

Um programa de redistribuição, por sua vez, praticado por uma instância central de governo, gera uma maior possibilidade de êxito, uma vez que é propiciado uma equalização mais equilibrada e, portanto, é capaz de promover a diminuição do fluxo migratório inter-regional.

Por fim, a fundamentação por via do critério de estabilização conforme observa Morais (2001), se dá pela esfera central de governo. Ela é a mais competente para a sua realização, visto que os bens públicos geridos nesse âmbito impactam de maneira equânime uma nação. Alguns exemplos disso são o combate a desequilíbrios externos e o controle da inflação. Entretanto, há uma necessidade dos entes subnacionais de auxiliarem esse processo, principalmente no que tange a política fiscal.

\section{MARCO REGULATÓRIO, DÍVIDA PÚBLICA ESTADUAL E DISTORÇõES NO FINANCIAMENTO PÚBLICO BRASILEIRO}

\subsection{Fragilização financeira estadual e o caminho para o Marco regulatório}

A fragilização financeira dos estados ao final da década de 1990 ensejou um conjunto normativo que atribuiu medidas a fim de reverter o quadro de deterioração fiscal que havia no Brasil. De acordo com Lopreato (2000) alguns fatores provocaram a fragilização das finanças estaduais ao final dessa década, dentre os quais cabe destacar a retomada da política de rigoroso controle de novas operações de crédito determinada pela Resolução n. 1.469 de 21/03/88, aliada às altas taxas de juros e à dificuldade de sustentar as relações financeiras no interior dos próprios estados. A falta de medidas para fazer frente a esse quadro obrigou os bancos públicos estaduais, 
em 1988 e 1989, a serem as válvulas de escape das unidades federativas, seja no âmbito estadual como também no municipal. Desse modo, verificou-se uma variação de 28,2 para $46 \%$ em apenas dois anos na liberação total dos empréstimos e financiamentos concedidos por eles. 0 que resultou em $77,8 \%$ (no ano de 1988) do valor total das operações de crédito dos bancos estaduais concentradas no setor público.

Por essa razão, observou-se a contração do giro dos empréstimos estaduais e um aumento no estoque da dívida, com correção monetária e taxas de juros incompatíveis com a evolução da receita fiscal, o que comprometeu as frentes de financiamento e ampliou os problemas de gestão da administração central, das empresas ou dos bancos estaduais. "A inadimplência do tesouro e das empresas, aliado ao alto custo de captação no mercado, envolveram as instituições financeiras na crise estadual." (LOPREATO, 2000, p. 12)

Não bastasse a fragilização dos estados acompanhar a "década perdida", essa conjuntura perdurou durante a década de 1990 também. Embora o processo de estabilização monetária com advento do plano real em julho de 1994 - trouxesse certo controle da inflação, adveio também o custo disso, uma política monetária restritiva. Assim, a taxa Selic real foi de $33,4 \%$ ao ano, o que onerou o refinanciamento das dívidas estaduais e municipais, e eliminou um importante mecanismo de equilíbrio orçamentário quando as despesas fixadas tiveram seu valor real corroído, e trouxe um elevado nível de renúncia de receitas, especialmente do ICMS (DIAS, 2004).

Nesse sentido, com base nesse quadro, o Governo Federal estipulou o primeiro marco regulatório frente ao problema fiscal, mediante a Medida Provisória 1.560/96, que autoriza a consolidação, assunção e refinanciamento, pela União, da dívida pública de responsabilidade dos estados e do Distrito Federal. Tal medida foi convertida na Lei $9.496 / 97$, que autorizou a União a realizar essas operações até 31 de março de 1998, prazo posteriormente prorrogado até 31 de maio de 2000.

A partir disso, os estados gradativamente assinaram contratos de refinanciamento de dívidas. Tais contratos "implicaram a emissão de $\mathrm{R} \$ 115,6$ bilhões em títulos de responsabilidade do Tesouro Nacional, sendo a mais relevante a operação relativa ao estado de São Paulo, com a emissão de R\$ 59,4 bilhões." (DIAS, 2004, p. 5)

Desse modo, o processo de endividamento estadual acabou se tornando um dos elementos centrais do ajuste em curso no período. Segundo Lopreato (2000), ele foi responsável, em 1998, por cerca de 13,5\% junto ao passivo do setor público, demonstrando sua gravidade na conjuntura nacional e impedindo os estados de darem continuidade a seus projetos de investimento. Tal processo resultou na negociação de recursos junto à União. 
Dessa forma, podem ser observados três elementos normativos no Brasil voltados para 0 equilíbrio das contas públicas e estabilização da dívida dos governos e que, portanto, estabeleceram o marco regulatório nesse período. Esse novo regime fiscal se deu quando 0 esgarçamento orçamentário do setor público brasileiro ensejou um marco regulatório ao final da década de 1990, que consagrou uma mudança na política macroeconômica brasileira, especialmente a parte fiscal, motivado por três pontos principais: i) contratos de refinanciamento dos estados; ii) observação da chamada Regra de ouro e busca do equilíbrio fiscal intertemporal; iii) e aprovação da Lei de Responsabilidade Fiscal (LRF)

A "Regra de ouro" está prevista na Constituição e, em seu art. 167, III estabelece:

Art. 167. São vedados: [...]

III - a realização de operações de créditos que excedam o montante das despesas de capital, ressalvadas as autorizadas mediante créditos suplementares ou especiais com finalidade precisa, aprovados pelo Poder Legislativo por maioria absoluta; [...]

(BRASIL, 1988, p. 103)

Assim, é possível observar o objetivo desta regra, o de evitar que se recorra ao endividamento público para custear despesas correntes, isto é, gastos que não levam diretamente à aquisição ou à formação de um bem de capital.

Além destas duas, destaca-se o coroamento de todo esse processo regulatório - a Lei de Responsabilidade Fiscal, (Lei Complementar $n^{0} 101$, de 04/05/2000) ${ }^{7}$. Tal Lei estabelece um código de conduta para a execução do gasto do governo por parte dos administradores públicos dos três entes federativos (união, estados e municípios). Ela possui quatro eixos de funcionalidade: Planejamento, Transparência, Controle e Responsabilização. Eixos fundamentais para 0 compromisso no cumprimento das metas fiscais, o que gera maior controle da relação endividamento/investimento.

Já em seu primeiro artigo, a LRF observa que as normas por ela estabelecidas estão voltadas para a responsabilidade na gestão fiscal, sendo esta definida em seu primeiro parágrafo como:

Art. $1[\ldots] \S 1^{\circ} \mathrm{A}$ responsabilidade na gestão fiscal pressupõe a ação planejada e transparente, em que se previnem riscos e corrigem desvios capazes de afetar o equilíbrio das contas públicas, mediante o cumprimento de metas de resultados entre receitas e despesas e a obediência a limites e condições no que tange a renúncia de receita, geração de despesas com pessoal, da seguridade social e outras, dívidas consolidada e mobiliária, operações de

\footnotetext{
${ }^{7}$ Disponível em: http://www.planalto.gov.br/ccivil_03/leis/LCP/Lcp101.htm. Acesso em: 07 jun. 2019.
} 
crédito, inclusive por antecipação de receita, concessão de garantia e inscrição em Restos a Pagar. (BRASIL, 2000)

Dessa forma, a LRF visa a proteger as contas públicas contra eventuais desequilíbrios causados por despesas de caráter continuado. São consideradas "despesas de caráter continuado" as obrigações rígidas, como salários e pagamento de aposentadorias. A LRF criou tetos para essas dívidas que consideram a arrecadação do nível federativo em questão. Um aumento dessas despesas não deve superar esse limite e deve-se provar previamente a origem desses recursos.

O não cumprimento da LRF por parte do governante faz com que o mesmo esteja sujeito a penalidades que também são chamadas de sanções. Existem dois tipos de sanções: as Institucionais, que estão previstas na própria LRF e as Pessoais, que estão previstas na lei de Crimes de Responsabilidade Fiscal. Alguns exemplos de sanções institucionais são: a suspensão de transferências voluntárias para os governantes que não realizarem previsão, arrecadação e cobrança de tributos que sejam de sua competência; suspensão da concessão de novas vantagens aos servidores, da criação de cargos, novas admissões e a da contratação de horas extras para o governante que exceder $95 \%$ no limite máximo de gastos com pessoal. Alguns exemplos de sanções pessoais são: perda de cargo, proibição de exercer emprego público, pagamento de multas e prisão.

Um dos alcances da LRF que aqui interessa ser debatido consiste no que diz respeito à dívida pública e mobiliária. ${ }^{8}$ Os limites globais estabelecidos para o montante da dívida adotam como base a dívida consolidada de todos os entes. Nesse sentido, a LFR prevê que a proposta que contém tais limites devem ser encaminhada pelo presidente da república ao Senado Federal, no prazo de noventa dias após a lei complementar ser publicada. Além disso, o projeto de lei que contém os limites para a dívida mobiliária federal deve ser apresentado ao Congresso Federal, ao mesmo tempo o esclarecimento de sua conformidade aos limites fixados para a dívida consolidada da União.

Embora a LRF tenha previsto a criação de tetos de endividamento público para todos os entes, essa questão não pode ser considerada inteiramente regulada. Isso porque, foram aprovados - por meio da Resolução do Senado Federal n 40, de 20/12/20019 - limites globais para os montantes de dívida apenas dos estados, do distrito Federal e dos municípios. De acordo

\footnotetext{
${ }^{8}$ As definições constam no art. 29 da LRF

9 Disponível em: http://www2.camara.leg.br/legin/fed/ressen/2001/resolucao-40-20-dezembro-2001429320normaatualizada-pl.pdf. Acesso em: 14 jun. 2019.
} 
com 0 art. $3^{0}$ da resolução, ficam definidos os limites da dívida consolidada líquida desses entes da seguinte forma:

Art. 3 [...]: I - no caso dos Estados e do Distrito Federal: 2 (duas) vezes a receita corrente líquida, definida na forma do art. 2; e II - no caso dos Municípios: a 1,2 (um inteiro e dois décimos) vezes a receita corrente líquida, definida na forma do art. 2. (BRASIL, 2001)

No caso da União, entretanto, nunca foi aprovada regulamentação específica determinando um limite para seu nível endividamento, apesar de já terem sido encaminhadas propostas.

\subsubsection{Financiamento público e o Sistema de Dívida Pública}

A composição dos tributos apresenta-se de três diferentes formas, sendo a primeira a forma federativa, que é a mais utilizada, e é aquela oriunda por nível de governo (União, Estado e Município), ou seja, por competência, além disso é definida na Constituição Federal. Já a segunda se dá por base de incidência, (consumo, mão de obra, lucro, finanças e patrimônio), enquanto a terceira por ordem de importância em termos de arrecadação.

Segundo Khair (2013) são avaliadas duas situações da composição federativa: a) arrecadação direta da União, Estado e Município, segundo determina a Constituição Federal; b) receita disponível, que é o valor que resta para cada ente da federação após as transferências constitucionais.

Somente quando se finalizam essas transferências é que se compõem as receitas disponíveis dos entes da federação. Por meio dela, portanto, os entes subnacionais (que compões a federação) realizam as suas despesas. Entretanto, não é a totalidade da receita disponível que pode/é utilizada pelos governos, uma vez que também são descontados os encargos com juros da dívida, que por sua vez são elevados, já que historicamente o Brasil apresenta uma elevada taxa básica de juros (Selic), causando uma indisponibilidade efetiva dos recursos. Isso compromete a disponibilidade efetiva que pode ser aplicada nos projetos e atividades dos entes e na amortização da dívida refinanciada dos estados e municípios maiores, que podem comprometer até $13 \%$ da Receita Líquida Real (RLR) (KHAIR, 2013).

Em seu Art. $2^{\circ}$, Parágrafo único, a Lei ${ }^{\circ} 9.496 / 97$ demonstra o conceito de RLR:

Entende-se como receita líquida real, para os efeitos desta Lei, a receita realizada nos doze meses anteriores no mês imediatamente anterior àquele em que se estiver apurando, excluídas as receitas provenientes de operações de crédito, de alienação de bens, de transferências voluntárias ou de doações recebidas com o fim específico de atender despesas de capital e, no caso dos estados, as transferências aos municípios por participações constitucionais e legais (BRASIL, 1997). 
Gráfico 2 - Evolução da carga tributária bruta e líquida (\%PIB)

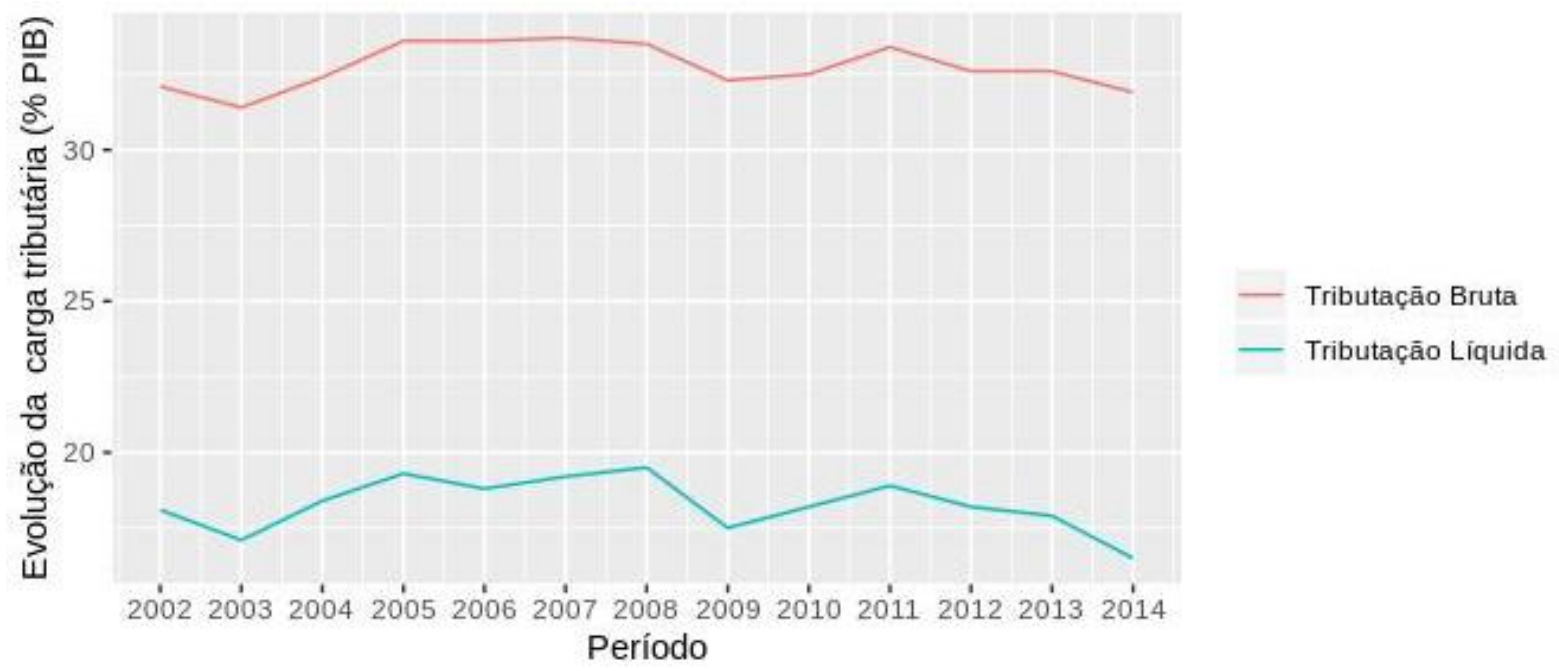

Fonte: RFB e STN. Elaboração própria.

O desempenho fiscal pelo lado da receita é, em certo grau, importante para a análise das condições de financiamento do gasto público. Nesse sentido, o gráfico 2 demonstra a evolução da carga tributária bruta ${ }^{10}$ e líquida ${ }^{11}$, o que nos permite observar, nos primeiros anos, uma forte tendência de elevação da arrecadação, em grande parte explicada frente ao ciclo de crescimento econômico que o país atravessou, via aumento dos preços das commodities no mercado internacional, e investimento público. Uma quebra estrutural ocorre a partir de 2008 devido à crise financeira, ao mesmo tempo a arrecadação bruta perde força devido ao menor crescimento econômico.

O crescimento seguinte se interrompe em 2011 devido ao aprofundamento da desaceleração econômica, diminuição dos empregos formais e pela política de desonerações fiscais concedidas pelo governo federal. ${ }^{12}$ Por outro lado, a carga tributária líquida, obteve variações com mais intensidade, caindo 10,3\% somente de 2008 para 2009 e 20,6\% entre 2011 e 2016. Assim, essa carga tributária encerrou 2016 no nível de 15\% do PIB, o menor para o período analisado, após cinco anos consecutivos de queda.

\footnotetext{
${ }^{10}$ Segundo definição da RFB, são considerados no cálculo da Carga Tributária Bruta (CTB) os pagamentos compulsórios (definidos em lei) realizados por pessoas físicas e jurídicas para o Estado, excluídos que configurem sanção, penalidade ou demais acréscimos legais.

${ }^{11}$ Segundo definição da SPE, a Carga Tributária Líquida retrata o impacto líquido da política fiscal sobre a renda disponível do setor privado, uma vez que considera as transferências realizadas pelo governo para este setor. Disponível em: http://www.spe.fazenda.gov.br/carga-tributaria-liquida. Acesso em: 21 jun. 2019.

12 Carvalho (2018) analisa de forma consistente o contexto e resultados de tal período para a economia brasileira.
} 
Quando se faz uma análise pelo lado do resultado entre as receitas e despesas, observase que nos últimos anos essa relação demonstra uma deterioração conforme a tabela abaixo:

Tabela 3 - Evolução das receitas e despesas do Governo central 2007 - 2012 (em \% do PIB)

\begin{tabular}{lllllll}
\hline & $\mathbf{2 0 0 7}$ & $\mathbf{2 0 0 8}$ & $\mathbf{2 0 0 9}$ & $\mathbf{2 0 1 0}$ & $\mathbf{2 0 1 1}$ & $\mathbf{2 0 1 2}$ \\
\hline Receita & 19,30 & 19,20 & 18,90 & 20,70 & 19,70 & 20,00 \\
Despesa & 21,50 & 20,10 & 22,20 & 21,90 & 21,90 & 21,40 \\
Pessoal & 4,40 & 4,30 & 4,70 & 4,40 & 4,30 & 4,20 \\
Custeio & 11,90 & 11,70 & 11,80 & 13,00 & 11,90 & 12,50 \\
Juros & 4,50 & 3,20 & 4,60 & 3,30 & 4,40 & 3,30 \\
Investimentos & 0,80 & 0,90 & 1,00 & 1,20 & 1,30 & 1,40 \\
Resultado & $-2,20$ & $-0,80$ & $-3,30$ & $-1,20$ & $-2,10$ & $-1,40$ \\
\hline
\end{tabular}

Fonte: RFB e STN. Elaboração: Amir Khair (2013).

Embora a receita tenha apresentado certo crescimento quando analisada em termos do PIB, tal crescimento não foi o suficiente para superar o movimento das despesas no período recente considerado. Diante de tal cenário nas contas públicas, o governo utiliza outras formas de financiamento do gasto, e isso se dá via dívida.

O sistema de dívida pública é composto por um conjunto de instituições financeiras e não financeiras, as quais podem ser privadas ou públicas. Neste sistema, o Banco Central do Brasil (BACEN) e a Secretaria do Tesouro Nacional (STN) constituem as principais instituições a fim de realizar a gestão estatal sob um conjunto bastante diversificado de agentes financeiros, tais como: bancos, corretoras, pessoas físicas ou jurídicas atuantes no mercado.

Trindade (2006) elenca três conjuntos de objetivos que expressam a centralidade da dívida pública, na totalidade da dinâmica de acumulação de capital, quais sejam: 1) Mobilização de capital de empréstimo global da economia; 2) A absorção e destruição de capital de empréstimo; 3) Financiamento do fundo público. Como elemento de análise deste trabalho, é importante ressaltar que a dívida pública constitui mecanismo singular de financiamento de parcela dos gastos estatais, dentre eles, destacam-se os referentes às chamadas despesas de capital, ou seja, infraestrutura e investimentos estatais.

Esse financiamento se faz necessário frente à insuficiência de investimentos privados em determinadas áreas do conjunto da economia. Uma boa aproximação do quadro de Formação 
bruta de capital fixo - variável que mede o investimento - nos setores de infraestrutura foi feita por Frischtak (2008) para o período 2001-2007:

Tabela 4 - Investimentos privados em infraestrutura, 2001-2007 (\%PIB)

\begin{tabular}{cccccccc}
\hline Setor & $\mathbf{2 0 0 1}$ & $\mathbf{2 0 0 2}$ & $\mathbf{2 0 0 3}$ & $\mathbf{2 0 0 4}$ & $\mathbf{2 0 0 5}$ & $\mathbf{2 0 0 6}$ & $\mathbf{2 0 0 7}$ \\
\hline Telecom & 1,69 & 0,66 & 0,47 & 0,69 & 0,66 & 0,53 & 0,49 \\
Energia elétrica & 0,32 & 0,33 & 0,25 & 0,22 & 0,23 & 0,25 & 0,29 \\
Saneamento & 0,01 & 0,04 & 0,03 & 0,02 & 0,02 & 0,02 & 0,02 \\
Transportes & 0,21 & 0,17 & 0,13 & 0,16 & 0,22 & 0,19 & 0,18 \\
Ferrovias & 0,06 & 0,05 & 0,06 & 0,10 & 0,15 & 0,11 & 0,10 \\
Rodovias & 0,13 & 0,11 & 0,06 & 0,05 & 0,06 & 0,06 & 0,06 \\
Portos & 0,02 & 0,01 & 0,01 & 0,01 & 0,01 & 0,02 & 0,02 \\
Total & 2,23 & 1,20 & 0,88 & 1,09 & 1,14 & 0,99 & 0,97 \\
\hline
\end{tabular}

Fonte: Frischtak (2008).

Com base na tabela, é possível identificar a concentração dos investimentos privados em setores como telecomunicações e energia elétrica, enquanto outras áreas fundamentais para garantir cidadania, como saneamento e transporte, contam com $0,2 \%$ do PIB em investimentos.

Diante desse quadro, o Estado - geralmente em momentos de baixa arrecadação tributária - por meio de seu mecanismo de dívida pública (nesse caso, trata-se da forma mobiliária), realiza operações de compra e/ou venda de títulos, para então pagar com uma taxa de juros - definida pelo Bacen, que é a Taxa Básica de Juros da Economia, chamada de Sistema Especial de Liquidação e de Custódia (SELIC).

Nesse sentido, "a dívida pública desenvolve um duplo movimento muito peculiar e necessário à regulação creditícia: o Estado toma empréstimo dando como contrapartida títulos de capital fictício" (TRINDADE, 2016. p. 184). Tal mecanismo de financiamento é importante principalmente em momentos de crise, onde o nível de emprego bem como o consumo das famílias diminui.

Portanto, conforme observou Trindade (2006, p. 162) "a dívida pública compõe não um fator isolado e fortuito necessário ao financiamento dos gastos estatais, mas sim um sistema, (...) um conjunto diferenciado de fatores que interagem e desenvolvem distintas funções" necessárias à "totalidade" do capital social. A partir disso, compreender os aspectos por trás da dinâmica do sistema de dívida pública brasileiro torna-se central para também compreender as desigualdades regionais de financiamento. 
De acordo com Oliveira (2009), a dívida pública apresenta-se sob diversas formas:

i) emissão de moeda, que representa um débito do Estado para com a sociedade; ii) contratual, que resulta de contratos assinados na aquisição de produtos, serviços e empréstimos realizados pelo setor público junto a agentes internos e/ou externos; iii) mobiliária, com a qual o governo obtém recursos que necessita vendendo título no mercado financeiro, com prazos determinados de resgate.

Tais formas de dívida, excetuando-se a emissão de moeda, implicam custos, e esses custos se determinam via taxa de juros, que mantém relação direta com seus prazos. Desse modo, para o governo torna-se mais atraente financiar suas necessidades de dívida através da emissão de títulos de curto prazo. Ademais, dentre essas formas, a dívida pode ser de origem interna ou externa. No caso da interna, ainda pode haver de alguns de seus componentes serem vinculados/atrelados às variações de moedas estrangeiras, como o dólar, por exemplo. (OLIVEIRA, 2009)

No Brasil, o critério de mensuração da dívida não é uma tarefa metodológica simples. A STN utiliza a categoria de Dívida Bruta do Governo Geral (DBGG). Tal categoria abrange em seu cálculo o passivo das três esferas de governo (federal, estadual e municipal), excluindo o Bacen. Além destes passivos, há também ativos na forma de reservas externas, créditos a receber, etc ${ }^{13}$. Conforme Oliveira (2009), a partir desses ativos deduzidos dos passivos, o país adota a Dívida Pública Líquida do Setor Público (DLSP).

De acordo com Oliveira (2009), uma análise mais detida da DLSP não é capaz de se desvincular de alguns aspectos: do comportamento das Necessidade de Financiamento do Setor Público (NFSP), tal medida é também conhecida como uma medida do "déficit público", sendo uma das principais causas de sua variação; das variáveis que afetam seu estoque, como as alterações na taxa de juros e Política cambial; e por fim, do Produto Interno Bruto (PIB), que é o papel denominador na relação de equilíbrio das contas públicas.

Apesar da DLSP ser a principal categoria utilizada pelo governo brasileiro para sinalizar sua capacidade de solvência fiscal, Khair (2013) alerta que tal categoria pode levar a erros na avaliação da saúde fiscal do setor público, haja vista não medir o correto impacto da política fiscal, frente a questões como transferências ao Banco Nacional do Desenvolvimento Econômico e Social (BNDES), e operações compromissadas realizadas pelo Bacen. Que levam a uma elevação no montante dos juros.

${ }_{13}$ Metodologia disponível em: https://dadosabertos.bcb.gov.br/dataset/13762-divida-bruta-do-governogeral--pib--metodologia-utilizada-a-partir-de-2008. Acesso em: 21 jun. 2019. 
Desse modo, 0 indicador do endividamento bruto mostra-se mais sensível a diferentes operações com impacto direto na dívida pública, assim, o gráfico a seguir demonstra a trajetória recente comparada dessas duas categorias no país, de modo que as ambas são crescentes desde o início de 2013. Isso reflete a deterioração do resultado primário, do resultado nominal e do PIB. $\mathrm{O}$ aumento das necessidades de financiamento não cobertas por receitas arrecadadas pelos governos regionais e pela união culminou no aumento das emissões de títulos conforme o gráfico abaixo:

Gráfico 3 - Dívida Bruta do Governo Geral e Dívida Líquida do Setor Público (\%PIB)

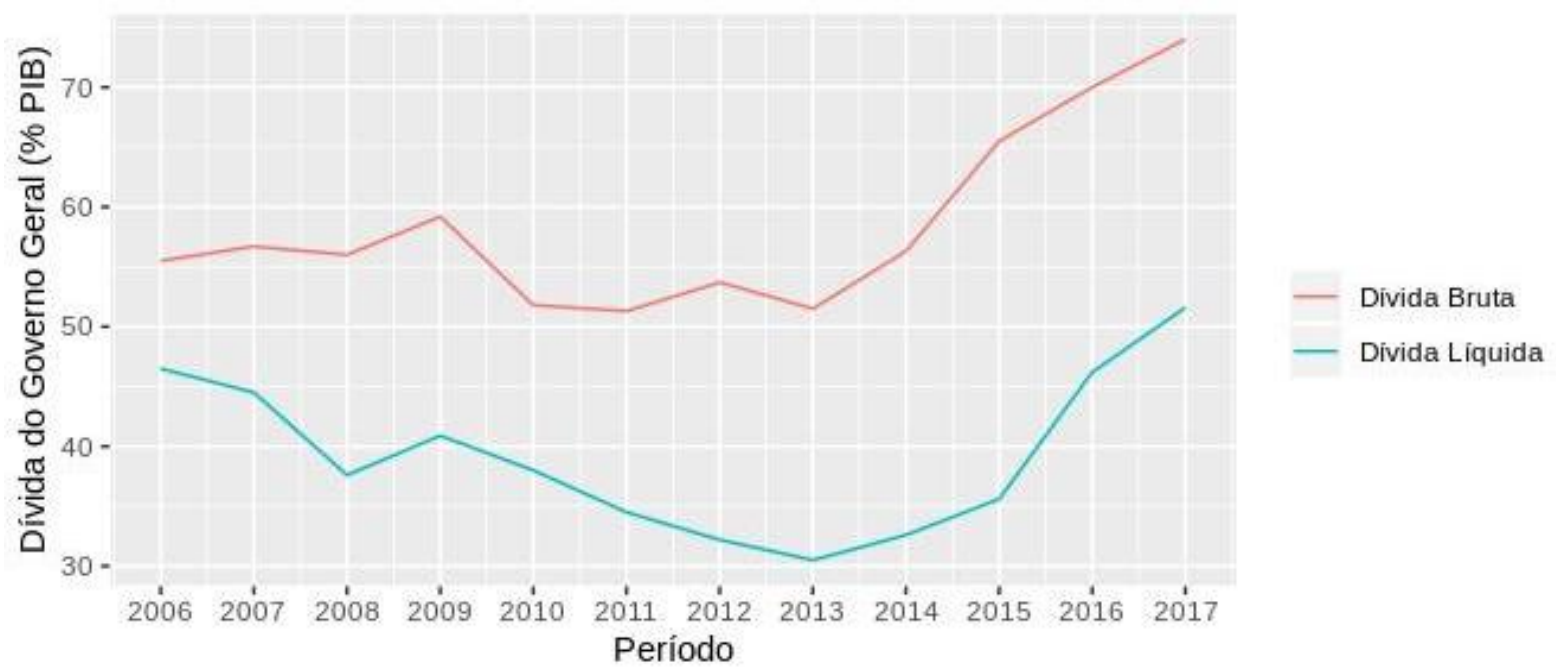

Fonte: BCB. Elaboração própria.

A partir do gráfico 3 pode-se observar que, entre 2009 e 2013, houve uma tendência decrescente tanto da DBGG quanto da DLSP, de modo que nesse período a DBGG passou de $59,2 \%$ do PIB para $51,5 \%$ do PIB e a DLSP de $40,9 \%$ do PIB para $30,5 \%$ do PIB. Assim, verificase uma escalada na trajetória de ambas as dívidas. A DBGG, que havia apresentado variações menores até 2013 , ficando entre $50 \%$ e $60 \%$ do PIB, alcançou $74 \%$ do PIB ao final de 2017 . A DLSP também cresce após 2013, com uma elevação de mais de 20\% do PIB, terminando 2017 com uma dívida de $51,6 \%$ do PIB.

\subsection{Aspectos metodológicos}

A fim de alcançar o objetivo pretendido deste trabalho, e para fins da pesquisa, optou-se por selecionar 5 (cinco) estados, sendo um de cada região do país, e que representem aquelas 
unidades subnacionais de maior expressividade e significância recente em termos quantitativos ${ }^{14}$ em ao menos duas (incluindo o volume de dívida) das seguintes grandezas: i) Dimensão econômica (PIB); ii) Dimensão populacional; iii) Dimensão do volume de dívida (em termos de dívida consolidada líquida15).

A adequação de cada estado ao regime fiscal não é o cerne do estudo, porém, aqui se busca uma análise de caráter geral (regional e federativo) a partir do recorte espacial adotado. A partir desses estados selecionados será possível analisar a verificação empírica de indicadores de estatística descritiva com a hipótese de inserção do componente subnacional estadual no novo marco regulatório presente na política econômica brasileira, qual seja, o de sustentabilidade intertemporal fiscal.

Portanto, para inferir possíveis conclusões a respeito do fenômeno a ser investigado e capturar elementos de ordem regional que caracterizam a natureza do financiamento, assim como também seu grau de heterogeneidade em termos de condições de investimento, temos os seguintes estados a serem investigados, na série histórica que vai de 2000 a 2013 , que estabelece o período subsequente ao redesenho institucional do novo regime fiscal e a quebra estrutural que a recessão provocou em 2014.

Quadro 3 - Unidades Federativas Analisadas

\begin{tabular}{c|c|c|c}
\hline Unidades Federativas & $\begin{array}{c}\text { PIB a preços constantes } \\
\text { (R\$ de 2013) }\end{array}$ & $\begin{array}{c}\text { População } \\
\mathbf{2 0 1 3}\end{array}$ & $\begin{array}{c}\text { Dívida Consolidada } \\
\text { Líquida }\end{array}$ \\
\hline PARÁ & 120.949 .000 .000 & 8.073 .924 & 1.378 .888 .000 \\
BAHIA & 204.265 .000 .000 & 15.126 .371 & 10.877 .168 .000 \\
GOIÁS & 151.010 .000 .000 & 6.523 .222 & 14.104 .042 .000 \\
SÃO PAULO & 1.708 .222 .000 .000 & 44.035 .304 & 183.764 .775 .000 \\
RIO GRANDE DO SUL & 331.095 .000 .000 & 11.207 .274 & 55.040 .941 .000 \\
\hline
\end{tabular}

Fonte: IBGE (2019); STN (2019); IPEADATA (2019). Elaboração própria

A partir dos parâmetros fiscais do setor público brasileiro a análise será construída mediante a observação dos seguintes blocos de indicadores de estatística descritiva e sua interação com as funções que a dinâmica fiscal de financiamento e investimento cumprem:

\footnotetext{
${ }_{14}$ Alguns valores numéricos a serem apresentados em gráficos e/ou tabelas foram devidamente deflacionados pelo IGP-M (índice geral de preços de mercado), a partir da ferramenta "Calculadora Cidadã" disponível no sítio virtual do Banco Central do Brasil (BCB) e tomando como base para o ajuste a mediana (mês de junho) do último ano da série histórica (2013).

15 Dívida Consolidada Líquida, conforme o manual de demonstrativos fiscais (MDF) da STN representa o montante da Dívida Consolidada (DC) deduzido o saldo relativo aos haveres financeiros (disponibilidade de caixa e demais haveres financeiros)
} 
Quadro 4 - Indicadores Utilizados

\begin{tabular}{|c|c|}
\hline Funcionalidade & Indicador Fiscal \\
\hline Financiamento & $\begin{array}{r}\text { Renda tributária disponível dos municípios brasileiros } \\
\text { Evolução da carga tributária bruta e líquida (\%PIB) }\end{array}$ \\
& $\begin{array}{r}\text { Dívida Bruta do Governo Geral e Dívida Líquida do Setor Público (\%PIB) } \\
\text { Resultado Primário (\%PIB) }\end{array}$ \\
& $\begin{array}{c}\text { Proporção entre Receita tributária federal e PIB } \\
\text { Receita via transferências da união (UF's Selecionadas - 2000/2013) } \\
\text { Receita via arrecadação de ICMS (UF's Selecionadas - 2000/2013) }\end{array}$ \\
\hline Investimento & Dívida líquida (UF's Selecionadas - 2000/2013) \\
& Investimento/PIB estadual (UF's Selecionadas - 2000/2013) \\
\hline
\end{tabular}

Fonte: Elaboração própria.

\section{CAPACIDADE DE INVESTIMENTO E DISTORÇÕES NO FINANCIAMENTO PÚBLICO: ANÁLISE DE DADOS}

O financiamento regional, (que se evidencia pela capacidade de financiamento dos entes estaduais) está inserido, na inclusão estrutural do país - a partir de processos normativos e políticos já considerados anteriormente - no novo regime fiscal, cujo elemento central, melhor se define a partir da compreensão de um novo papel relegado à política fiscal, qual seja, o de buscar a suavização intertemporal da relação dívida/PIB.

Com base no exposto, e partindo então do primeiro bloco de funcionalidades assumido como referência metodológica empírica para este trabalho - o do financiamento, é possível analisar as disparidades regionais neste âmbito.

Para compreender as diferenças estaduais de financiamento é preciso, antes de tudo, compreender a trajetória recente de um indicador que verifica a sustentabilidade da política fiscal por parte da união, essa análise mais ampla será utilizada como efeito de comparação dos resultados a nível estadual. Tal indicador trata-se do Resultado Primário. De acordo com Khair (2013) ele corresponde à diferença entre receitas e despesas primárias - isto é, desconsiderando o pagamento de juros. Tal mecanismo surgiu de um acordo com o Fundo Monetário Internacional em 1999, por meio do Regime de Metas de Superávit Primário. Por meio desse regime, o governo passou a se comprometer com uma meta para o resultado primário, fixada na Lei de Diretrizes Orçamentárias. Ele é utilizado como uma âncora que sinaliza a possibilidade de o governo arcar 
com o pagamento da dívida pública. O gráfico a seguir, mostra a evolução do resultado primário do Governo Central (\%PIB):

\section{Gráfico 4 - Resultado Primário (\%PIB)}

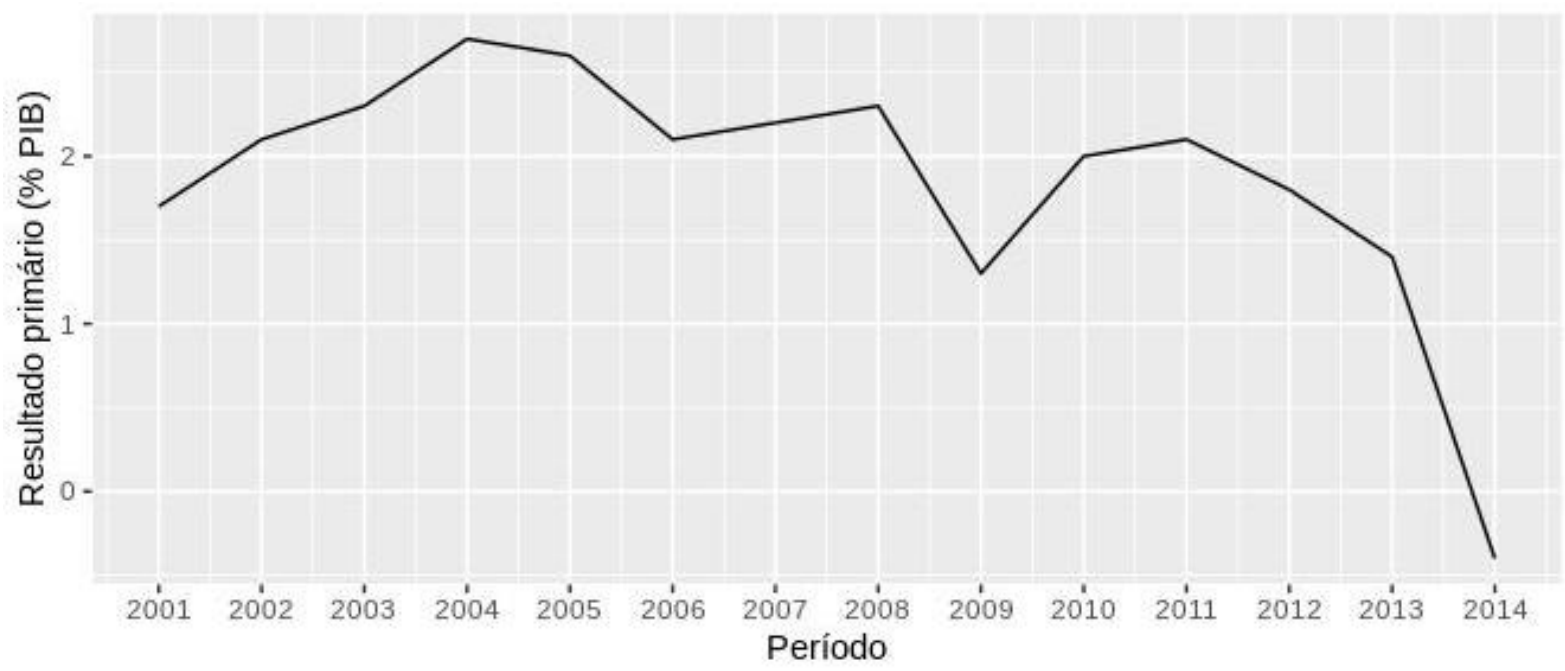

Fonte: BCB. Elaboração própria.

Entre os anos de 2002 e 2008 o Resultado Primário variou em torno de um superávit de $2,5 \%$ do PIB, mas os resultados da crise internacional foram sentidos no país em 2009 quando houve uma quebra estrutural da trajetória. Por fim, partiu para uma trajetória descendente a partir de 2012, alcançando um déficit de $1,8 \%$ do PIB em 2017, após um déficit de 2,6\% do PIB no ano anterior.

Ademais, com base nessa dinâmica, e de forma equivalente à busca de superávits primários, a união procura assegurar níveis adequados da receita via carga tributária. É fundamental o esforço de obtenção de receita positiva para a remuneração dos fluxos de capital de empréstimo, deslocados para o país na forma de obrigações contraídas pelo Tesouro, em consonância com a entrada em definitivo do país (em nível federal e estadual) no mercado de dívida pública em regime de mundialização financeira. 0 gráfico a seguir defronta a trajetória mensal das receitas tributárias - sob o regime de competência total, relacionado a arrecadação em proporção ao PIB para o período em análise 2000-2013:

Gráfico 5 - Proporção entre Receita tributária federal e PIB 


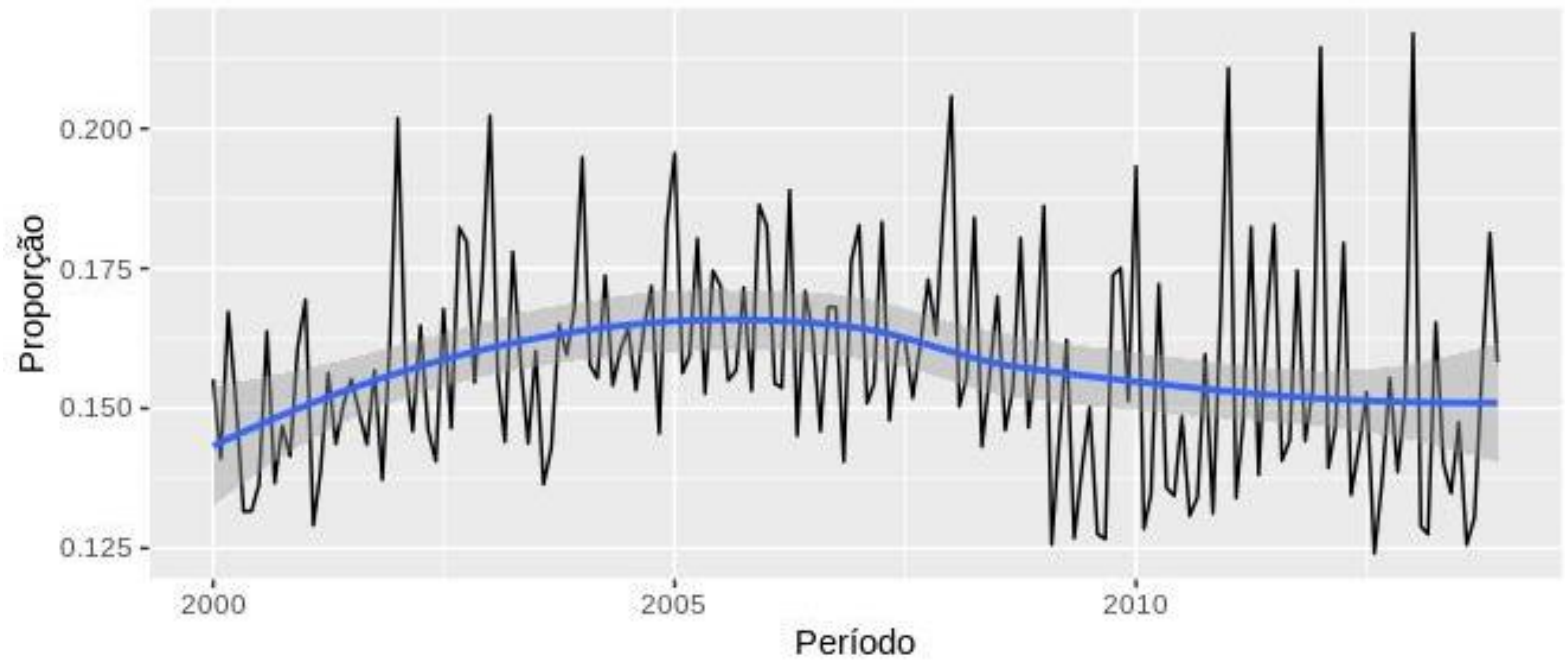

Fonte: Sistema Gerenciador de Séries Temporais. BCB. Elaboração própria.

Enquanto o gráfico 4 traz a série histórica da diferença entre as receitas e despesas primárias, assumindo como base a proporção do PIB, o gráfico 5 assume como base também a proporção ao PIB porém se encarregando de mostrar a trajetória da receita via tributos, a fim de evidenciar o esforço da esfera federal em manter o nível de receita adequado às mudanças no conjunto da economia. Nesse sentido, é possível observar o valor mais alto de 16,2\% em 2006 no âmbito da análise da média anual, seguido por uma trajetória de queda a partir de 2008. Além disso, os níveis mais altos na análise mensal são explicados por fatores de sazonalidade, mas também variação do PIB (recessão ou períodos de crescimento), chegando a $21,7 \%$ em janeiro de 2013 e 12,5\% em agosto do mesmo ano.

Outro aspecto do financiamento a ser tratado diz respeito à renda tributária. Tal categoria do orçamento público remete ao problema dos desequilíbrios regionais. Nesse sentido, Cossio (1998) diferencia duas formas de desequilíbrio que podem revelar diferenças capazes de afetar o financiamento regional. O primeiro deles consiste na relação desigual entre capacidade tributária e nível de gastos das várias esferas de governo, trata-se do desequilíbrio vertical, o qual reflete nas desigualdades entre os níveis de governo. O segundo deles, e que este trabalho vai se deter é o desequilíbrio horizontal, ele é caracterizado pelas diferenças de capacidade tributária e dos custos dos gastos públicos do mesmo nível de governo nas diferentes regiões de um país. Este desequilíbrio é capaz de refletir, portanto, as desigualdades regionais.

Nesse sentido, é possível observar para os estados elencados, com base no gráfico 5 , uma trajetória de crescimento em toda a série histórica analisada. Tal trajetória corrobora para 0 fato de que a CF/88 privilegiou a primeira distribuição de recursos, a vertical, que se dá entre os níveis de governo. Ao mesmo tempo ela relegou ao segundo plano a distribuição horizontal dos 
recursos, que se traduzem pela reduzida importância dos fundos regionais, constituídos de somente $3 \%$ da arrecadação do IR e do IPI, e os poucos dispositivos constitucionais que mencionam a redução das disparidades regionais como objetivo primordial da aplicação dos gastos do governo.

Gráfico 6 - Receita via transferências da união (UF's Selecionadas - 2000/2013)

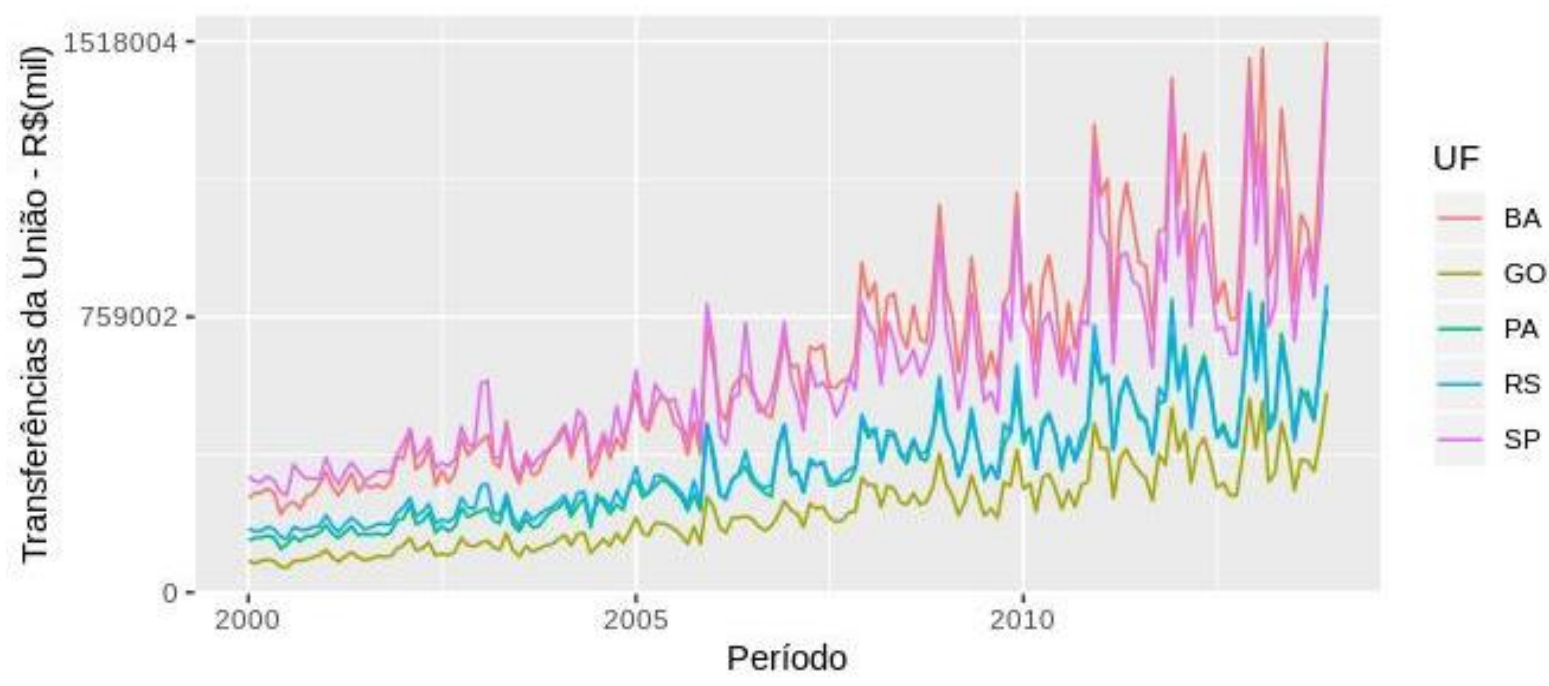

Fonte: Sistema Gerenciador de Séries Temporais. BCB. Elaboração própria.

Embora seja possível a argumentação de que o desequilíbrio entre as transferências para as unidades federativas corresponda a necessidades de financiamento. É possível, entretanto, identificar na diferença constante de distribuição uma questão estrutural. Isso porque - como pode ser verificado no gráfico acima, onde se assume a série mensal 2000 - 2013 como base - a discrepância de distribuição de receita pela união explica-se pelas diferenças de população, com São Paulo e Bahia liderando o recebimento desses recursos em todo o período analisado e em valor superior às demais regiões, das quais deve-se destacar as regiões norte e sul, que em poucos indicadores fiscais mantêm uma trajetória semelhante.

Em junho de 2000, as transferências para o estado do Pará atingiram seu menor nível para o período analisado, com o valor de $\mathrm{R} \$ 119.991 .000,00$, que após isso, manteve uma trajetória cíclica, chegando ao valor máximo de R 798.791.000,00 em fevereiro de 2013. Enquanto isso, para o mesmo período, Goiás apresentou o menor nível de receita, o estado do Rio grande do Sul apresentou em seu maior nível de receita 49.402.000,00 a mais do que o estado do Pará. Ao mesmo tempo São Paulo passou de R $268.508 .000,00$ em julho de 2000 para R\$ 1.465.652.000,00 no último mês de 2013, de modo que suas transferências cresceram 5,4 vezes ao longo da série. 0 crescimento dessas transferências mesmo em momentos de desaceleração econômica que o governo federal enfrentou revela a tentativa do governo de caminhar na direção 
de uma redistribuição fiscal, estando tal tentativa, no entanto, limitada às transferências verticais, com uma metodologia que não atacam o problema da real necessidade de financiamento dos estados com menor nível de renda.

Gráfico 7 - Receita via arrecadação de ICMS (UF's Selecionadas - 2000/2013)

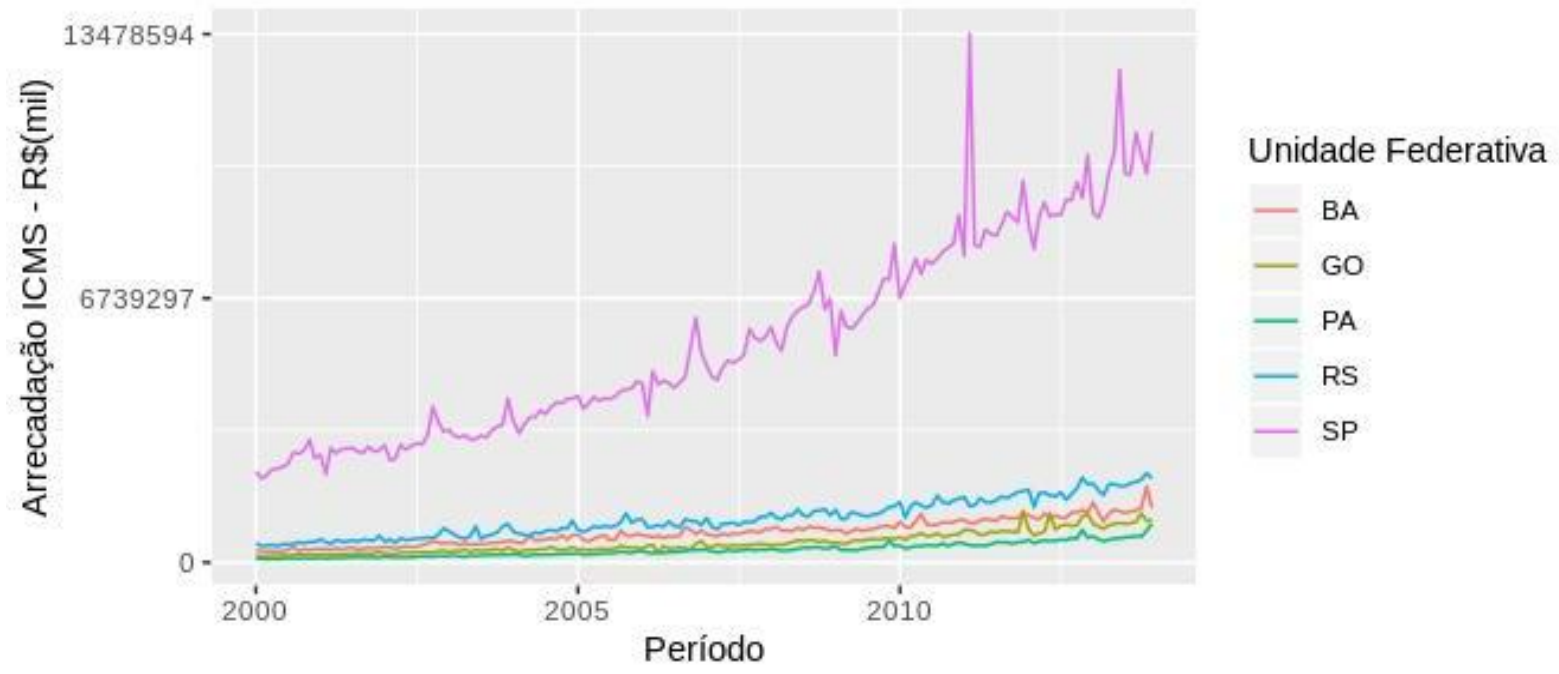

Fonte: Sistema Gerenciador de Séries Temporais. BCB. Elaboração própria.

O gráfico acima expressa a arrecadação de ICMS para as unidades federativas elencadas, tal tributo é uma das principais fontes de receitas da esfera estadual. Os dados demonstram uma tendência de maior arrecadação para os estados das regiões sul e sudeste do país (representadas pelos estados de SP e RS).

Essa tendência reafirma a alta capacidade em termos de infraestrutura e nível de produtividade frente a uma menor capacidade de condição de geração de receitas pelos estados do Norte, como no caso do Pará, o qual obteve o menor desempenho de arrecadação durante toda a série histórica. Os estados da Bahia e Goiás são portadores de trajetórias mais ou menos similares, se comparados aos dois primeiros, tanto em termos de evolução quanto de magnitude da massa tributária.

Nesse sentido, a investigação das razões que permitiram a Amazônia assumir papel secundário no desenvolvimento brasileiro e apresentar uma trajetória de baixo grau de arrecadação, passa pela decomposição de tais valores. 0 gráfico 6 traz a evolução da receita via arrecadação de ICMS, o principal instrumento tributário dos estados. Todos os entes apresentaram taxa de crescimento positiva de suas trajetórias de arrecadação. Os estados do Pará e Goiás apresentaram crescimento de $162 \%$ e $143 \%$, respectivamente, não suficiente para atingir um patamar razoável e necessário para seus financiamentos. Sendo um possível condicionante explicativo desse comportamento o benefício que esses entes tiveram no período de alta dos 
preços das matérias-primas constituintes de ampla parcela de seus produtos internos, com irradiação de efeitos internos indiretos sobre suas receitas próprias.

Após um crescimento relativamente sustentado entre 2000 e 2012, São Paulo apresenta um crescimento com maior intensidade em 2013 atingindo $R \$ 12.565 .989 .000,00$ de arrecadação em junho do mesmo ano. Enquanto o Rio Grande do Sul, segundo em termos gerais, alcança R\$ 2.276.685.000,00. Goiás $\mathrm{R} \$ 1.256 .468 .000,00$, Bahia $\mathrm{R} \$ 1.936 .724 .000,00$, ambos em 2013, e 0 Estado do Pará apresenta em seu ápice $\mathrm{R} \$ 996.067 .000,00$ no último mês da série.

Tal padrão de financiamento aufere aos estados uma maior autonomia para determinar alíquotas e conceder isenções no ICMS (a chamada Guerra fiscal), nessa guerra, ganham os estados mais desenvolvidos, com melhores condições locacionais e maior aporte financeiro e político, portanto, além de prejudicar estados com baixa arrecadação, ela aprofunda as desigualdades regionais.

Por fim, a outra categoria analisada neste trabalho trata do Investimento público, ele pode ocorrer também, via dívida estadual. De acordo com Mora (2002), a renegociação da dívida estadual ao final da década de 1990 envolveu $77,9 \%$ da dívida líquida dos estados, e, portanto, também dos municípios, desse modo, cerca de $11,3 \%$ do PIB. Tal renegociação ensejou um ajuste financeiro, fiscal e patrimonial que levaram os estados a provocar superávits primários, que viabilizaram grande parte do pagamento dos juros e amortizações das dívidas negociadas, ocasionando uma tendência de melhora no quadro e a possibilidade de novos investimentos via novas dívidas. O gráfico abaixo demonstra a trajetória da dívida liquida para as unidades selecionadas: 
Gráfico 8 - Dívida líquida (UF’s Selecionadas - 2000/2013. Médias anuais em Milhões R\$)

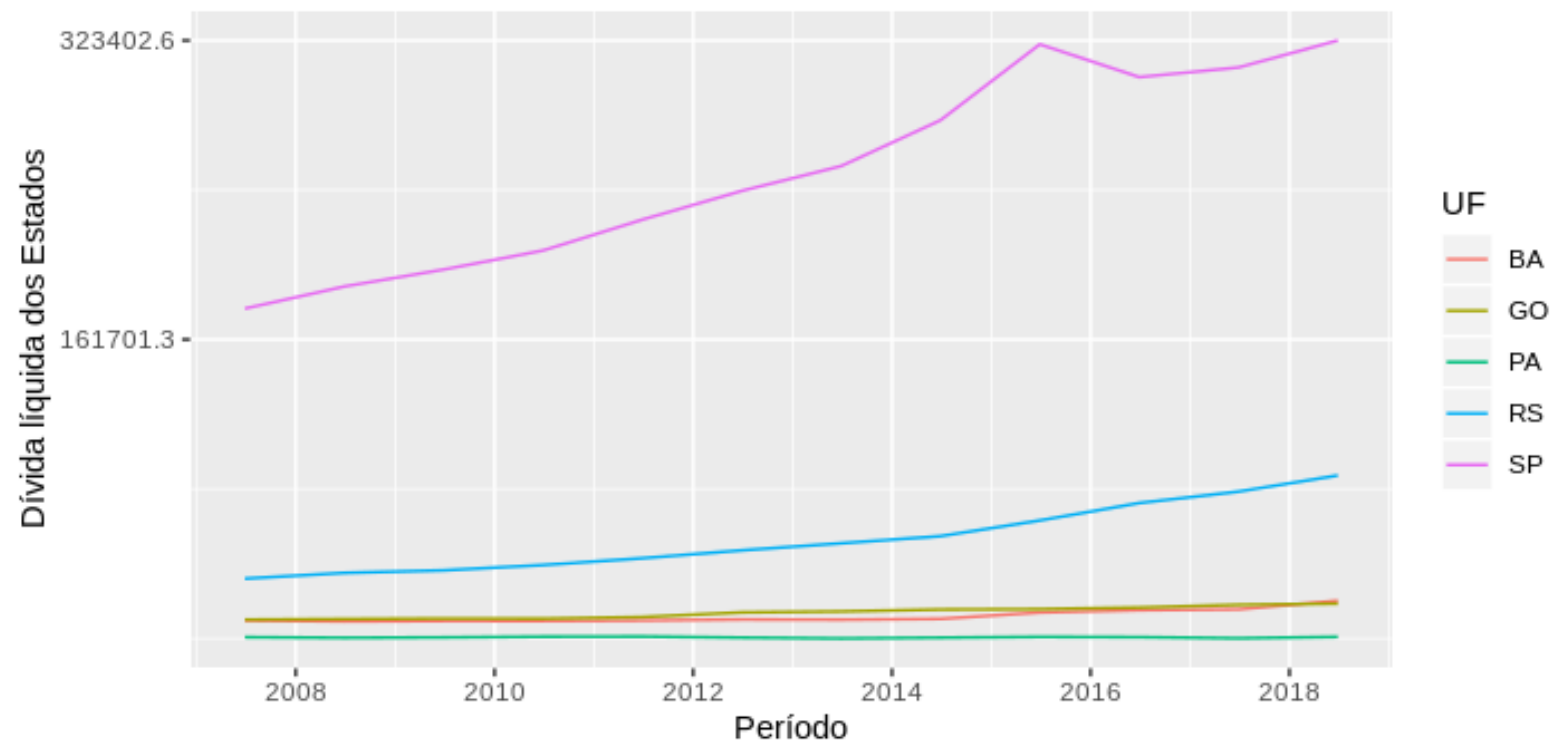

Fonte: Sistema Gerenciador de Séries Temporais. BCB. Elaboração própria.

O gráfico apresenta uma tendência de aumento do endividamento líquido estadual ao longo da série. Cabe destacar o curso de endividamento dos estados de Goiás, Bahia e Pará que expressam baixo volume de dívida frente aos demais. São Paulo e Rio Grande do Sul, apresentam uma concentração do passivo (323402.6 milhões e 91850,65 milhões, respectivamente) e uma trajetória de crescimento, que muito se explica pela capacidade de receita para solver os compromissos de dívida uma vez que são protagonistas nas regiões de maior dimensão econômica do país.

Deste modo, portanto, há um movimento de adequação por parte desses Estados aos imperativos da nova fiscalidade em curso, o que permitiria, abrir espaço para contratação de novas operações de crédito, conforme se depreende da leitura dos regulamentos instituídos (Lei de Responsabilidade Fiscal e Lei n. 9496/1997).

O baixo volume da dívida líquida dos estados que apresentam os menores patamares no gráfico, como no caso do Pará, indica a possibilidade de contratação de novas operações de crédito, para investimento público, mediante análise do Senado Federal. O gráfico abaixo demonstra o curso desse investimento (em infraestrutura e compra de bens de capital) ao longo da série analisada: 
Gráfico 9 - Investimento/PIB estadual (UF's Selecionadas - 2000/2013)

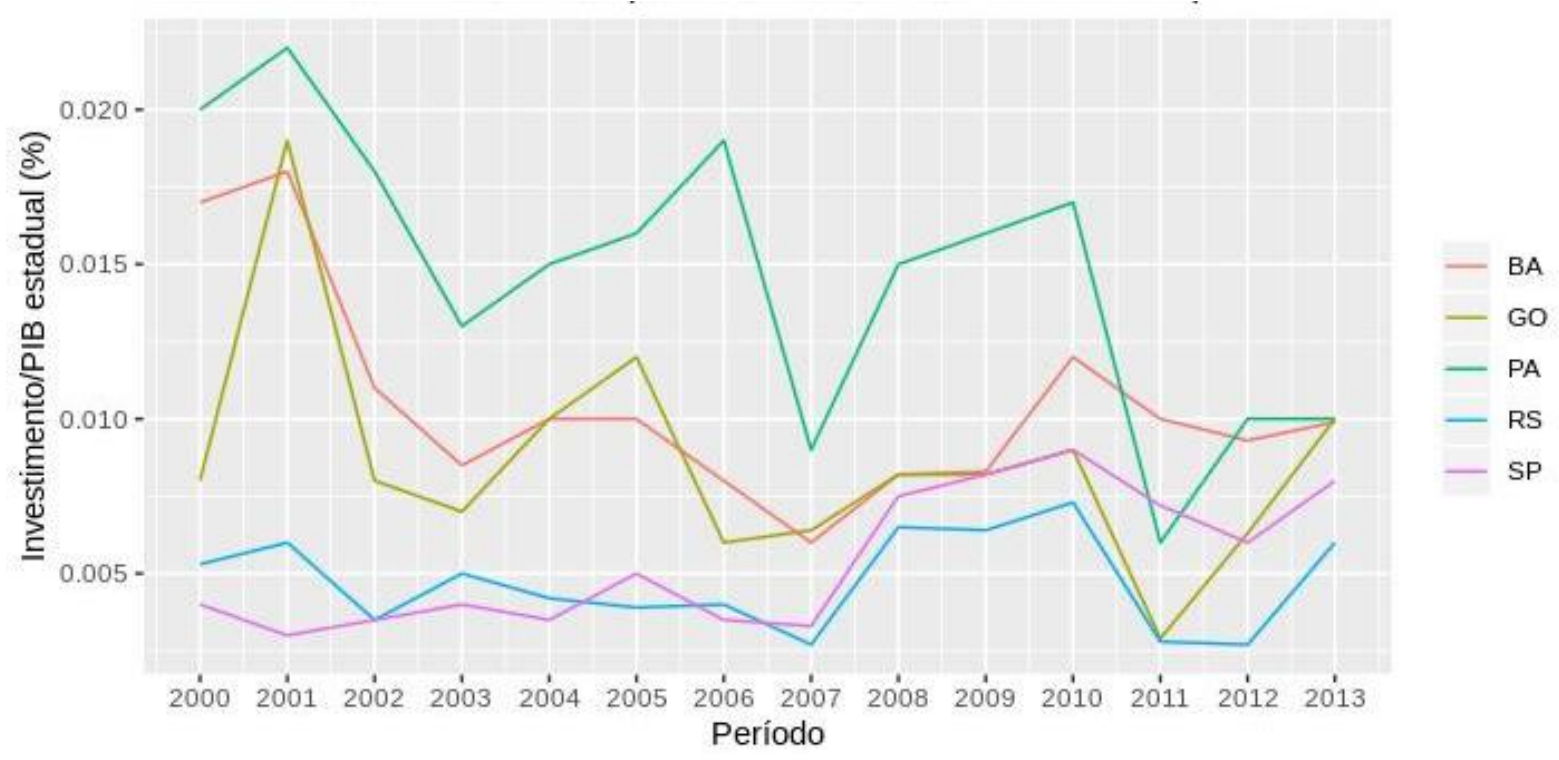

Fonte: Execução Orçamentária dos Estados (STN). Elaboração própria.

O gráfico demonstra uma tendência de baixos investimentos públicos como proporção ao PIB das unidades analisadas, ressaltando que o país não privilegia a atuação estadual em mobilizar recursos para tal aspecto. É possível observar também, que os estados que possuem maior diversificação econômica, apresentam investimentos reduzidos em proporção ao PIB, tal fato explica-se não só pelo reduzido investimento, mas também pelo alto nível do PIB.

Os estados do Pará, Bahia e Goiás partem de níveis superiores do indicador, e apresentam trajetória de diminuição ao longo da primeira metade da série a níveis que se aproximam e até mesmo chegam a menos de $1 \%$ do PIB, o que condiz, como dito acima, que 0 pais não privilegia o investimento frente à preocupação dos governos ao estabelecimento do marco regulatório em frear os gastos utilizando este componente das despesas como variável de ajuste primordial, ao lado do esforço de arrecadação e da consequente redução da relação dívida/receita.

Posteriormente à um breve crescimento entre 2007-2010, as trajetórias estaduais de despesa com investimento voltam a pender, e se estabilizam ao final da série próximas do $1 \%$ do PIB estadual, revelando uma tendência explícita de baixa contribuição do setor público na formação bruta de capital fixo. 


\section{CONSIDERAÇÕES FINAIS}

Os conflitos existentes dentro da forma de governo estatal que é o Federalismo, demonstram grande relação com a existência do poder de jurisdição por parte de um governo central, ao mesmo tempo em que nele há outros governos com jurisdições regionais e com distintos graus de autonomia. Desse modo, tais conflitos perpassam também ao âmbito do Federalismo Fiscal, que corresponde ao conjunto de mecanismos técnicos e jurídicos que balizam a distribuição da competência tributária entre os diferentes níveis de governo.

Os conflitos do Federalismo fiscal ganharam outros atores e mecanismos a partir da aprovação da CF/88. Ela trouxe o caráter da descentralização na política fiscal, garantindo maior autonomia aos entes, porém revelando desequilíbrios horizontais. De modo que a baixa capacidade de obtenção de recursos tributários da maior parte das unidades inferiores de governo determine que o sistema de transferências intergovernamentais (da União para as demais unidades federativas) constitua-se na principal fonte de financiamento de grande parte dos estados e municípios que formam o sistema federativo brasileiro.

Isso resulta em uma estrutura de financiamento marcada pela baixa capacidade de obtenção de recursos tributários de algumas unidades federativas e a real necessidade de corrigir tais desequilíbrios por intermédio de transferências que objetivem reduzir o problema da desigualdade horizontal.

Nesse sentido, a exploração dos resultados e práticas fiscais entre as regiões brasileiras no período 2000-2013, sob o ponto de vista do financiamento e investimento, permitiu a identificação da ainda restrita capacidade da união em garantir uma distribuição equitativa de sua receita tributária aos estes estaduais.

A experiência de atraso no padrão de desenvolvimento regional brasileiro, se mostrou em diferentes formas, em uma delas se observou o saque de recursos na Amazônia Legal, onde foi engendrada uma ocupação histórica de território, marcada com a realização de projetos de inserção dela no capital internacional, e que foram necessariamente ineficientes e ineficazes.

Dessa forma, em termos regionais, verifica-se que os estados de regiões mais desenvolvidas (São Paulo e Rio Grande do Sul), com volumes consideravelmente maiores de dívida líquida, em que pese o considerável esforço de geração de superávits primários ao longo da série, obtêm menor dificuldade em cumprir com investimentos em infraestrutura e em capital, o que se evidencia em trajetórias de dívidas crescentes, ao passo que suas receitas via transferências e arrecadação própria se mostram também em níveis elevados. Os estados da Bahia, Goiás e Pará, por outro lado, embora apresentaram comportamento mais favorável em 
termos de declínio de dívida e, portanto, adequação à LRF, obtiverem resultados desfavoráveis quanto a arrecadação própria e sobretudo, transferências constitucionais.

A trajetória dos investimentos dos estados analisados é, em geral baixa para o período em questão. Desse modo, se observou que a série termina com um teto de 1\%, o que permite maiores críticas a respeito das limitações impostas aos entes estaduais no que se refere ao manejo de suas receitas próprias. Desse modo, se observa uma restrição à autonomia dos governos em aplicarem maiores recursos na consecução de empreendimentos de infraestrutura, bem como na oferta de serviços e políticas públicas.

\section{REFERÊNCIAS BIBLIOGRÁFICAS}

Abrucio, L. F. (2002). Descentralizaçao e Coordenaçao Federativa no Brasil: Lições dos Anos FHC. In: L. F. Abrucio, \& M. G. Loureiro, O Estado numa era de reformas: os anos FHC (pp. 143246 ). Brasília: Minstério do Planejamento.

ANDERSON, George. Federalismo: uma introdução. Rio de Janeiro: FGV, 2009.

BRASIL. Legislação Federal. Lei no 5.172, de 25 de outubro de 1966 - Acessado em 23 de abril 2019 em: http://www.planalto.gov.br/ccivil_03/leis/L5172.htm.

Legislação Federal. Lei Complementar no 62, de 28 dezembro de 1989.

Acessado em 23 de abril de 2019: http://www.planalto.gov.br/ccivil_03/Leis/LCP/Lcp62.htm

Constituição (1988). Constituição da República Federativa do Brasil: texto constitucional promulgado em 5 de outubro de 1988. 35. ed. - Brasília: Câmara dos Deputados, Edições Câmara, 2012. 454 p. (Série textos básicos n. 67).

Lei Complementar n. 101, de 4 de maio de 2000. Estabelece normas de finanças públicas voltadas para a responsabilidade na gestão fiscal e dá outras providências. Brasília, 2000. Disponível em: <http://www.planalto.gov.br/ccivil_03/leis/LCP/Lcp101.htm >. Acesso em: 14 jun. 2019.

Lei $\mathrm{n}^{\circ}$ 9496, de 11 de setembro de 1997. Estabelece critérios para a consolidação, a assunção e o refinanciamento, pela União, da dívida pública mobiliária e outras que especifica, de responsabilidade dos Estados e do Distrito Federal. Diário Oficial da República Federativa do Brasil, Brasília, 12 set., 1997.

CARVALHO, Laura. Valsa brasileira: do boom ao caos econômico. $1^{\text {a }}$. ed. São Paulo: Todavia, 2018. $192 \mathrm{p}$.

COSSIO, F. A. B. Disparidades econômicas inter-regionais, capacidade de obtenção de recursos tributários, esforço fiscal e gasto público no federalismo fiscal brasileiro. $21^{\circ}$ Prêmio BNDES de Economia. Rio de Janeiro. 1998.

DIAS, Fernando Alvares Correia. O Refinanciamento dos Governos Subnacionais e o Ajuste Fiscal 1999/2003. Texto para discussão. Consultoria Legislativa do Senado Federal: coordenação de estudos, Brasília, n. 17, dez. 2004. 
FRISCHTAK, C. 0 investimento em infra-estrutura no Brasil: Histórico recente e perspectivas. São Paulo: Pesquisa e planejamento econômico, v. 38 n.2, 2008.

KHAIR, A. A questão fiscal e o papel do Estado. São Paulo: Editora Fundação Perseu Abramo, 2013.

LASSANCE, A. Federalismo no Brasil: Trajetória institucional e alternativas para um novo patamar de construção do Estado. p. In: LINHARES, P. T. F.; MENDES, C. C.; LASSANCE, A. (Org.) Federalismo à Brasileira: questões para discussão. Brasília: IPEA, 2012.

LOPREATO, Francisco Luiz C. Caminhos da política fiscal do Brasil. São Paulo: Unesp. IE Unicamp, 2013.

0 endividamento dos governos estaduais nos anos 90. Texto para discussão. IE/UNICAMP, Campinas, n. 94, mar. 2000.

MENDES, M., R.B. MIRANDA \& F.B. COSIO. Transferências intergovernamentais no Brasil: diagnóstico e proposta de reforma. Texto para Discussão $n^{\circ} 40$, de abril de 2008 . Consultoria Legislativa do Senado Federal - Coordenação de estudos. Acessado em 23 de fevereiro de 2019 em:

http://www.senado.gov.br/senado/conleg/textos_discussao/TD40MarcosMendes_RogerioBoueri_ FernandoB.Cosio.pdf

MORA, Mônica. Federalismo e Dívida Estadual no Brasil. Texto para discussão. IPEA, Rio de Janeiro, n. 866, mar. 2002.

MORAIS, M R.. As relações intergovenamentais na República Federativa da Alemanha Uma análise econômico-institucional. 22. ed. São Paulo: Konrad-Adenauer-Stiftung, 2001. v. 1. 383p.

MUSGRAVE, Richard A. \& MUSGRAVE, Peggy B. Finanças Públicas: teoria e prática. Tradução de Carlos Alberto Braga. Rio de Janeiro: Campus; São Paulo: Ed. Da USP 1980.

OATES, W. E. Fiscal federalism. New York: Harcourt Brace Jovanovich Inc., 1972.

OLIVEIRA, F. A. Economia e política das finanças públicas no Brasil. São Paulo: Editora Hucitec, 2009. 325 p.

A evolução da estrutura tributária e do fisco brasileiro: 1889-2009. Brasília: Ipea, 2010. (Texto para Discussão, n. 1.469)

QIAN, Y.; WEINGAST, B. R. Federalism as a Commitment to Preserving Market Incentives. The Journal of Economic Perspectives, v. 11, n. 4, p. 83-92, 1997.

REZENDE, F. Finanças Públicas. São Paulo: Atlas, 1984.

jun.-set. 1995.

Federalismo Fiscal no Brasil. Revista de Economia Política, v. 15, n. 3 (59),

Modernização tributária e federalismo fiscal. In: REZENDE, F.; OLIVEIRA, F. A. Descentralização e federalismo fiscal no Brasil: desafios da reforma tributária. Rio de Janeiro: Konrad Adenauer Stiftung, 2003, 336p.

SANTOS, D. F. C. Evolução financeira dos Estados, 2002-2016. Porto alegre, 2017. 
SANTOS, A. M. S. P., COSTA, L. S., ANDRADE, T. A. Federalismo no Brasil: análise da descentralização financeira da perspectiva das cidades médias. In: ANDRADE, T. A., SERRA, R. V. (Orgs.). Cidades médias brasileiras. Rio de Janeiro: IPEA, 2001, pp. 251-294.

SHAH, Anwar. The new fiscal federalism in Brazil. World Bank, 1992 (Discussion Paper, 124).

TIEBOUT, C. M. A Pure Theory of Local Expenditures. Journal of Political Economy, v. 64, n. 5, p. 416-424, 1956.

TRINDADE, J. R. B. Dívida Pública e Teoria do Crédito em Marx: Elementos Para Análise das Finanças do Estado Capitalista. 2006. 246 p. Tese (Doutorado em Desenvolvimento Econômico) - Programa de Pós-Graduação em Desenvolvimento Econômico, Universidade Federal do Paraná, Curitiba.

As Finanças dos Municípios Paraenses: Ensaio analítico sobre as receitas de transferências e de suas principais despesas sociais. Redes (Santa Cruz do Sul. Online), v. 18, p. $246-273,2013$.

WERNECK, R. (1992). Fiscal federalism and stabilization policy in Brazil. Texto para Discussão, n. 282. Rio de Janeiro: Departamento de Economia da PUC-RJ.

Recebido em 05 de Maio de 2020.

Aceito para publicação em 08 de Outubro de 2020.

\section{FEDERALISMO FISCAL E AMAZÔNIA: O FINANCIAMENTO PÚBLICO DIANTE DAS CONTRADIÇÕES REGIONAIS NO BRASIL}

\section{RESUMO}

O Federalismo fiscal no Brasil, sob a Constituição de 1988, estabelece a representação do sistema tributário brasileiro e a distribuição de competências tributárias correspondentes aos distintos níveis de governo. No entanto, essa estrutura sugere, além dos instrumentos e recursos tributários, a existência de disparidades socioeconômicas inter-regionais. Nesse sentido, o presente trabalho objetiva compreender as relações federativas nacionais e suas contradições regionais. Bem como, analisar o contexto federativo brasileiro e especificamente sua relação com as condições de financiamento e investimento público da Amazônia vis-à-vis as demais regiões. $O$ parâmetro para a avaliação dessas disparidades tratou de experiências concretas estaduais, elegendo cinco unidades federativas brasileiras - um de cada região - para tratamento comparativo, pela apresentação e análise de indicadores econômicos que possibilitem compreender os estados foco de análise.

Palavras-chave: Amazônia; capacidade fiscal; disparidades inter-regionais; federalismo fiscal; investimento público.

AMAZON AND TERRITORY: THE BRAZILIAN DEVELOPMENT PATTERN AND ITS IMPACTS ON REGIONAL DYNAMICSABSTRACT

\section{ABSTRACT}


Fiscal Federalism in Brazil, under the Constitution of 1988, establishes the representation of the Brazilian tax system and the distribution of tax competencies corresponding to the different levels of government. However, this structure suggests, in addition to the tax instruments and resources, the existence of interregional socioeconomic disparities. In this sense, the present work aims to understand the national federative relations and their regional contradictions. As well, to analyze the Brazilian federal context and specifically its relation with the conditions of financing and public investment of the Amazon with the other regions. The parameter for the evaluation of these disparities dealt with concrete state experiences, choosing five Brazilian federal units - one from each region - for comparative treatment, through the presentation and analysis of economic indicators that make it possible to understand the states of analysis.

Keywords: Amazônia; fiscal capacity; interregional disparities; fiscal federalism; public investment 